\title{
Good year ahead for science and technology
}

Tokyo

ANOTHER austere budget is on its way for Japan in 1985. Science and technology seem exempt from the general gloom, however, as the government struggles with its colossal deficit. Draft budgets for all the science-based ministries have been approved by the Cabinet, and show rises of between 3 and 12 per cent (see p. 256).

The new budget has yet to pass through the Diet, but cuts are not thought likely in the appropriations for science. The opposition parties will instead find plenty to disagree with in the planned reorganization of the health payment system and in the increases in the defence budget.

The increases for science, added to the ending of a few older big projects, are making it possible for all the science ministries to get several new schemes off the ground.

Science and Technology Agency (STA) Several years of massive expenditure on the preparations for the Expo 85 International Science Exposition are now practically over. With the opening scheduled for 17 March, expenditure for the 1985 fiscal year will decrease by 65 per cent, providing some spare funds that can go elsewhere.

A big increase is made possible for Special Promotion Funds - essentially equivalent to the grants from the Ministry of Education. Science and Culture (MESC) in aid of research and used to support a host of small projects. Indeed, although the fund was set up only a few years ago, it is now worth nearly 20 per cent of MESC's grants.

The really big news for STA, however, is that a hefty budget allocation $(1,400$ million yen) has been made for the design of modules to comprise a part of the US space station. No final decision has yet been made on the extent of Japanese participation in the US project, but this first move makes likely a major effort later; Mitsubishi Heavy Industries is to be the main contractor.

Money has also been provided for the HII rocket (Y7,300 million and guarantees of further sums over the next few years for the rocket, and Y1,500 million for further research on its cryogenic engine). So despite criticism that the project is merely duplicating other nations' achievements and that satellites could be launched more cheaply by the United States or Europe, it seems that Japan will really insist on having an independent launch capability by the early 1990 s. The rocket will be able to carry only a modest $2,000-\mathrm{kg}$ satellite into orbit and it will not be able to handle the huge communications satellites now coming into use - but that still leaves a large part of the satellite market (perhaps as much as $\mathbf{8 5}$ per cent) open to a potential Japanese competitor.

The new rocket does not exhaust STA's plans for massive new hardware. Money is also being provided to design a new deepsea diving vessel. Four years ago, the "Shinkai 2000" submersible made a successful 2,000-metre dive; now work on a manned vessel capable of reaching 6,000 metres is to go ahead at the Japan Marine Science and Technology Centre.

In basic science, there will be a considerable increase (to Y2,500 million) in the Institute of Physical and Chemical Research (RIKEN)'s nuclear research budget. This will allow construction to continue of a heavy-ion cyclotron - planned to be the most powerful in the world.

Heavy ions also feature in another continuing STA programme for the medical use of accelearators. The project, at the National Institute of Radiological Science, is using heavy ions, including those of carbon, neon, silicon and argon, to treat tumours, apparently with some success. The only other such facility is at the Lawrence Berkeley Laboratory in the United States, although a laboratory at the University of Alberta, Canada, is expected to be set up soon.

In the biological sciences, Y187 million has been provided to set up a gene bank - all the rage this year, it seems. Both the Ministry of Agriculture, Forestry and Fisheries (budget Y391 million) and the Ministry of Health and Welfare (budget Y107 million) have also just set up their own gene banks.

Modest gains are also seen for nuclear energy research and project Monju, the prototype fast breeder reactor, gets a considerable budget increase - but not enough to stop the project falling well behind schedule.

Project ERATO - Japan's bid to stimulate creativity through the encouragement of fairly eccentric group research (see Nature 305,$373 ; 1983$ ) - will take up two new themes this year: one on the physics of the nanometre region (in preparation for yet smaller devices) and one on atomic interactions at surfaces.

Ministry of Education, Culture and Science (MESC)

Grants in aid of research increase a little - but only a little more than the rate of inflation. Postdoctoral fellowships will become available for the first time. Only 72 (instead of the expected 200) of the Y200,000 (US\$800) a month fellowships will actually be of fered (and another 72 of lesser worth for those still studying for a doctoral degree) but the holders will be en- titled to apply for a considerable research grant, the first time that MESC has taken a serious step towards providing independent research support for young people. It is hoped that the number of fellowships will be expanded to 500 by 1989 but there are some doubts - even the funds for this project were at first refused by the Ministry of Finance.

Increases in funding have also been made for a number of categories of grant and numerous new projects launched. One project scheme - probably unique to Japan - is that of tokutei research. Grants are given to a subject area rather than to a specific group and anyone working in that area becomes entitled to apply for a part of the funds - the aim being to give a boost to a whole sub-discipline (sometimes involving more than 100 people) rather than to one research team. Among the nine new projects to begins this year are those on dynamic processes of material transport and transformation in the Earth's interior, the role of calcium ions in cellular regulation and nucleic acid conformation and its recognition. Total funds available run to Y5,300 million.

MITI

For MITI the big news is that a new "basic technology research promotion centre" is to be set up. The catch is that it is to be done in partnership with the Ministry of Posts and Telecommunications which had been lobbying for a similar institution to promote sophisticated regional telecommunications systems. The new centre will provide loans for basic research by private industry and set up new joint research projects. Relations between the two ministries are at an exceedingly low ebb as they struggle to gain control of computers and telecommunications research - the Ministry of Posts being badly wounded by the privatization of the telecommunications monopoly NTT - so it is expected to be some time before the organization is under way.

Two new-year "large-scale industrial projects" are also to be launched by MITI, one on flexible data base systems and one (the "aqua renaissance" project) to find ways of purifying and recycling water from industrial waste. Each will receive Y20 million in their start-up year. A separate project (budget Y70 million) for "next generation industries" will also begin for development of materials for optical components that will soon sit in optical fibre transmission lines and, one day, in the optical computer.

Alun Anderson

\section{Correction}

IN the article on the Austrian dam on the Danube (Nature 17 January, p.171), it was incorrectly stated that the Danube Commission had set up an ecological study. That has in fact been done on the initiative of the Austrian and Czechoslovak governments. 